\title{
Ohmic Hetero-Junction of n-Type Silicon and Tungsten Trioxide for Visible-Light Sensitive Photocatalyst
}

\author{
Masaharu Yoshimizu1, Yuki Hotori², Hiroshi Irie 1,2,3 \\ ${ }^{1}$ Special Doctoral Program for Green Energy Conversion Science and Technology, Interdisciplinary Graduate School of Medicine \\ and Engineering, University of Yamanashi, Yamanashi, Japan \\ ${ }^{2}$ Special Doctoral Program on Clean Energy, Interdisciplinary Graduate School of Medicine and Engineering, University of \\ Yamanashi, Yamanashi, Japan \\ ${ }^{3}$ Clean Energy Research Center, University of Yamanashi, Yamanashi, Japan \\ Email: hirie@yamanashi.ac.jp
}

How to cite this paper: Yoshimizu, M., Hotori, Y. and Irie, H. (2017) Ohmic Hetero-Junction of n-Type Silicon and Tungsten Trioxide for Visible-Light Sensitive Photocatalyst. Journal of Materials Science and Chemical Engineering, 5, 33-43.

https://doi.org/10.4236/msce.2017.58004

Received: July 13, 2017

Accepted: August 12, 2017

Published: August 15, 2017

Copyright (๑) 2017 by authors and Scientific Research Publishing Inc. This work is licensed under the Creative Commons Attribution International License (CC BY 4.0).

http://creativecommons.org/licenses/by/4.0/

\begin{abstract}
Visible light-sensitive photocatalyst was developed by combining n-type silicon ( $\mathrm{n}-\mathrm{Si}$ ) and tungsten trioxide $\left(\mathrm{WO}_{3}, \mathrm{n}-\mathrm{Si} / \mathrm{WO}_{3}\right)$, yielding an ohmic contact in between. In this system, the ohmic contact acted as an electron-and-hole mediator for the transfer of electrons and holes in the conduction band (CB) of $\mathrm{WO}_{3}$ and in the valence band (VB) of $\mathrm{n}-\mathrm{Si}$, respectively. Utilizing thusconstructed $\mathrm{n}-\mathrm{Si} / \mathrm{WO}_{3}$, the decomposition of 2-propanolto $\mathrm{CO}_{2}$ via acetone was achieved under visible light irradiation, by the contribution of holes in the $\mathrm{VB}$ of $\mathrm{WO}_{3}$ to decompose 2-propanol and the consumption of electrons in the $\mathrm{CB}$ of $\mathrm{n}$-Si to reduce $\mathrm{O}_{2}$. The combination of p-type $\mathrm{Si}(\mathrm{p}-\mathrm{Si})$ and $\mathrm{WO}_{3}(\mathrm{p}-\mathrm{Si} /$ $\mathrm{WO}_{3}$ ), not the ohmic contact but the rectifying contact, was much less effective, compared to $\mathrm{n}-\mathrm{Si} / \mathrm{WO}_{3}$.
\end{abstract}

\section{Keywords}

Ohmic Contact, Silicon, Tungsten Trioxide, Visible Light, Oxidative Decomposition, Two-Step Excitation

\section{Introduction}

Various photocatalytic materials have been evaluated for the oxidative decomposition of organic stains and production of hydrogen $\left(\mathrm{H}_{2}\right)$ via water splitting for environmental preservation and generation of clean energy, respectively, by utilizing solar energy [1] [2] [3]. Among examined materials, titanium dioxide $\left(\mathrm{TiO}_{2}\right)$ with which Fujishima and Honda first demonstrated photo induced wa- 
ter-splitting [1] is the most promising photocatalysts due to their high performance, abundance, nontoxicity, thermal stability and high resistance against photo-corrosion [2] [3]. Despite these advantageous properties, $\mathrm{TiO}_{2}$ is only sensitive to ultraviolet (UV) light and therefore requires modification for the utilization of visible light. To this end, numerous studies have examined the effects of doping foreign elements into $\mathrm{TiO}_{2}[4]$ and other UV-light sensitive photocatalysts, such as strontium titanate $\left(\mathrm{SrTiO}_{3}\right)$ [5], zinc oxide ( $\left.\mathrm{ZnO}\right)$ [2] [3] and so on. Another common method is to produce or find photocatalysts with narrow band-gaps which can absorb visible light [6] [7] [8] [9]. From these studies, combined systems consisting of two such narrow band-gap photocatalysts (PC1/ PC2) have been devepoled, such as tungsten disulfide $\left(\mathrm{WS}_{2}\right) /$ tungsten trioxide $\left(\mathrm{WO}_{3}\right)$, cobalt oxide $\left(\mathrm{Co}_{3} \mathrm{O}_{4}\right)$ /bismuth vanadate $\left(\mathrm{BiVO}_{4}\right)$, and so on (Type I in scheme 1) [10] [11] after the suggestions made in the literatures as to the more efficient charge separation in the combined system of $\mathrm{TiO}_{2}$ and cadmium sulfide (CdS), iron oxide $\left(\mathrm{Fe}_{2} \mathrm{O}_{3}\right), \mathrm{WO}_{3}, \mathrm{ZnO}$, cupper oxide $\left(\mathrm{Cu}_{2} \mathrm{O}\right)$, or bismuth oxide $\left(\mathrm{Bi}_{2} \mathrm{O}_{3}\right)$ etc., resulting in the increase in the lifetime of the charge carriers and the enhancement of the activity [12] [13]. However, all these combined systems are not recommended from the viewpoint of oxidation and reduction potentials of holes and electrons, respectively, after their interparticle transfer because the oxidation power of the holes and reduction powers of the electrons become weak after the transfer (Type I in Scheme 1).

To overcome the decrease in the oxidation power of the holes and reduction powers of the electrons, the insertion of a conducting layer (CL, metal such as gold $(\mathrm{Au})$, silver $(\mathrm{Ag})$, and tungsten $(\mathrm{W})$ or reduced graphene oxide (RGO)) between two types of photocatalysts was reported [14]-[20] (PC1/CL/PC2, Type II in Scheme 1). Regarding the powdered system, $\mathrm{CdS} / \mathrm{Au} / \mathrm{TiO}_{2}, \mathrm{WO}_{3} / \mathrm{W} /$ titanium doped-lead bismuth niobium oxide $\left(\mathrm{PbBi}_{2} \mathrm{Nb}_{1.9} \mathrm{Ti}_{0.1} \mathrm{O}_{9}\right)$ were reported for the decomposition of organic substances [14] [15]. For the overall water-splitting under visible light, ruthenium $(\mathrm{Ru})$-loaded rhodium-doped $\mathrm{SrTiO}_{3}$ (Ru-STO:Rh)/RGO/bismuth vanadate $\left(\mathrm{BiVO}_{4}\right)$, zinc rhodium oxide $\left(\mathrm{ZnRh}_{2} \mathrm{O}_{4}\right)$ / $\mathrm{Ag} /$ silver antimonite $\left(\mathrm{AgSbO}_{3}\right)$ and $\mathrm{ZnRh}_{2} \mathrm{O}_{4} / \mathrm{Ag} /$ bismuth vanadate $\left(\mathrm{Bi}_{4} \mathrm{~V}_{2} \mathrm{O}_{11}\right)$ were reported [16]-[20]. In addition, direct connection of the two or more types of photocatalysts without the conducting layer was also reported based on the

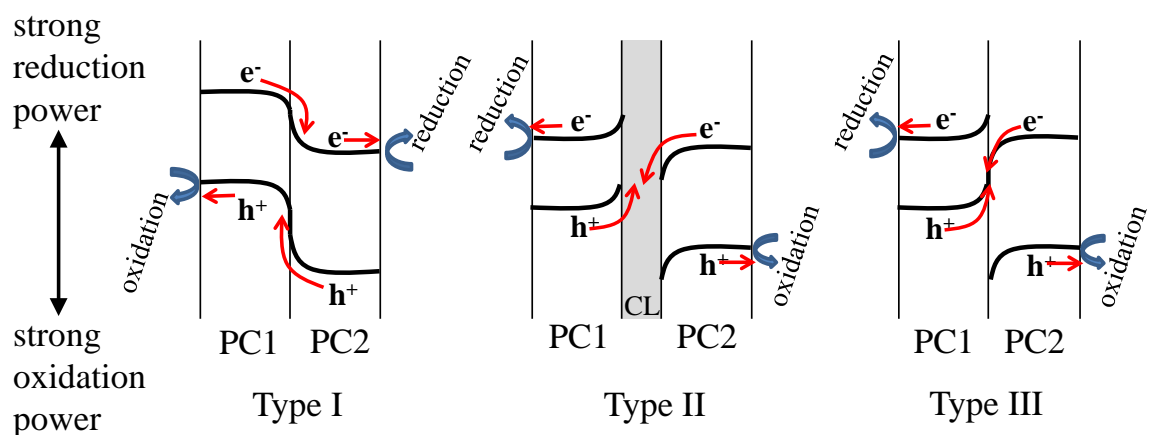

Scheme 1 . Three types of previously proposed heter-junctioned photocatalysts. 
concept of ohmic contact (PC1/PC2, Type III in Scheme 1). In most cases, they were a photoelectrochemical (PEC) electrode water-splitting systems, such as n-type silicon $(\mathrm{n}-\mathrm{Si}) / \mathrm{Fe}_{2} \mathrm{O}_{3}$, galium indium phosphorus $\left(\mathrm{GaInP}_{2}\right) /$ galium arsenic (GaAs), three types of amorphous $\mathrm{Si}$, and so on [21] [22] [23]. As for the powdered system, cupper bismuth oxide $\left(\mathrm{CuBi}_{2} \mathrm{O}_{4}\right) / \mathrm{WO}_{3}$ for the oxidative decomposition of acetaldehyde, and $\mathrm{Ru}-\mathrm{STO}: \mathrm{Rh} / \mathrm{BiVO}_{4}$ and $\mathrm{ZnRh}_{2} \mathrm{O}_{4} /$ defective $\mathrm{AgSbO}_{3}$ for the overall water-splitting were reported [17] [24] [25]. However, no experimental evidences for the formation of the ohmic contact were demonstrated in all cases but only provided the concept of the ohmic contact. Thus in the present study, we demonstrated that the formation of the ohmic contact could produce a more efficient photocatalyst than that of the rectifying contact by connecting $\mathrm{n}$-Si or p-type silicon (p-Si) with $\mathrm{WO}_{3}\left(\mathrm{n}-\mathrm{Si} / \mathrm{WO}_{3}, \mathrm{p}-\mathrm{Si} / \mathrm{WO}_{3}\right)$.

\section{Experimental Section}

\subsection{Preparations of $\mathrm{n}-\mathrm{Si} / \mathrm{WO}_{3}$ and $\mathrm{p}-\mathrm{Si} / \mathrm{WO}_{3}$ Electrodes}

Single crystaln-Si(100) and p-Si(100) wafers with a thickness of $525 \pm 25 \mu \mathrm{m}$ were purchased from Kyodo International Inc. The $\mathrm{n}-\mathrm{Si}(100)$ and $\mathrm{p}-\mathrm{Si}(100)$ wafer surfaces were cleaned by a RCA cleaning method [26]. That is, the successive immersions of the wafers in a boiling mixture of $95 \%$ sulfuric acid $\left(\mathrm{H}_{2} \mathrm{SO}_{4}\right)$ and $30 \%$ hydrogen peroxide $\left(\mathrm{H}_{2} \mathrm{O}_{2}\right)$ at a volume ratio of 3:1, in a 5\% hydrofluoric acid (HF) solution for $5 \mathrm{~min}$, in a boiling mixture of $25 \%$ aqueous ammonium $\left(\mathrm{NH}_{3}\right), 30 \% \mathrm{H}_{2} \mathrm{O}_{2}$ and distilled water at a volume ratio of 1:1:3 for 15 min, again in the $5 \% \mathrm{HF}$ solution for $5 \mathrm{~min}$, and in a $40 \%$ ammonium fluoride $\left(\mathrm{NH}_{4} \mathrm{~F}\right)$ solution for $5 \mathrm{~min}$ [26]. On the cleaned $\mathrm{n}-\mathrm{Si}(100)$ or $\mathrm{p}-\mathrm{Si}(100)$ surface, a $\mathrm{WO}_{3}$ film was deposited by sputtering a W metal target under oxygen $\left(\mathrm{O}_{2}, 40 \mathrm{SCCM}\right) /$ argon (Ar, $60 \mathrm{SCCM}$ ) gas mixture and $1.5 \mathrm{~Pa}$ for $16 \mathrm{~min}$ at substrate temperature of $400^{\circ} \mathrm{C}$, using a radio frequency $(\mathrm{RF})$ magnetron sputtering apparatus (Tokuda, Model CFS-8EP). The thickness was controlled to be $\sim 200 \mathrm{~nm}$.

\subsection{Preparations of $\mathrm{n}-\mathrm{Si} / \mathrm{WO}_{3}$ and $\mathrm{p}-\mathrm{Si} / \mathrm{WO}_{3}$ Powders}

To obtain $\mathrm{n}-\mathrm{Si}$ and $\mathrm{p}-\mathrm{Si}$ powders, the purchased $\mathrm{n}-\mathrm{Si}(100)$ and $\mathrm{p}-\mathrm{Si}(100)$ wafers, respectively, were roughly pulverized by a mortar and then finely pulverized using a planetary ball-milling apparatus at $500 \mathrm{rpm}$ for $5 \mathrm{~min}$ before use. Then $\mathrm{WO}_{3}$ was loaded by a liquid phase deposition (LPD) on the surface of either pulverized $\mathrm{n}$-Si or $\mathrm{p}$-Si powder as follows [27]. Briefly, $5.01 \mathrm{~g}$ of tungsten acid $\left(\mathrm{H}_{2} \mathrm{WO}_{4}\right.$, Kanto Chemical) was dissolved in $50 \mathrm{~mL}$ of an aqueous solution of $2 \%$ HF. $7.45 \mathrm{~g}$ of boric acid $\left(\mathrm{H}_{3} \mathrm{BO}_{3}\right)$ was dissolved in $50 \mathrm{~mL}$ of distilled water and was used as the reagent which acts as $\mathrm{F}^{-}$scavenger. These two solutions were mixed to use as the reaction solution for $\mathrm{WO}_{3}$ deposition. $7.72 \times 10^{-2} \mathrm{~g}$ of either pulverized $\mathrm{n}-\mathrm{Si}$ or $\mathrm{p}-\mathrm{Si}$ powder $\left(\mathrm{Si} / \mathrm{WO}_{3}=1 / 60 \mathrm{wt} \%\right.$ or $\left.1 / 7.3 \mathrm{~mol} \%\right)$ was stirred with the mixed solution using a magnetic stirrer for $6 \mathrm{~h}$ at room temperature. The reaction product was obtained by a filtration, followed by washing with sufficient distilled water and drying at $50^{\circ} \mathrm{C}$. Then the samples were heated at 
$500^{\circ} \mathrm{C}$ for $1 \mathrm{~h}$ in air.

\subsection{Characterizations}

The crystal structures of the prepared $\mathrm{n}-\mathrm{Si} / \mathrm{WO}_{3}$ and $\mathrm{p}-\mathrm{Si} / \mathrm{WO}_{3}$ electrodes and powders were examined by X-ray diffraction (XRD) using a PW-1700 system (Panalytical). A scanning transmission electron microscope (SEM, Hitachi, S-4500) was used to observe the morphology of the prepared samples. UV-visible absorption spectra for the $\mathrm{n}-\mathrm{Si} / \mathrm{WO}_{3}$ and $\mathrm{p}-\mathrm{Si} / \mathrm{WO}_{3}$ powders were obtained by the diffuse reflection method using a V-650 (JASCO) spectrometer.

The current-voltage (I-V) analysis in the presence or absence of light from a Xe lamp (LA-251Xe, Hayashi Tokei)for the $\mathrm{n}-\mathrm{Si} / \mathrm{WO}_{3}$ and $\mathrm{p}-\mathrm{Si} / \mathrm{WO}_{3}$ electrodes were performed in a conventional two electrode system using a potentiostat at (Hokuto Denko, HSV-10). To serve an ohmic electrode, platinum was deposited on $\mathrm{WO}_{3}$ using a quick coater (Sanyu Electron Co., Ltd., SC-708) and indium (Kanto Chemical) was attached on either n-Si or p-Si.

The photocatalytic activity of the $\mathrm{n}-\mathrm{Si} / \mathrm{WO}_{3}$ and $\mathrm{p}-\mathrm{Si} / \mathrm{WO}_{3}$ powdered photocatalysts were evaluated by the oxidative decomposition of gaseous 2-propanol irradiated with visible light $\left(>420 \mathrm{~nm}, 1 \mathrm{~mW} / \mathrm{cm}^{2}\right)$ from the Xe lamp (the same above) equipped with a glass filter (Y-44, HOYA). For the analysis, $300 \mathrm{mg}$ of the photocatalyst was uniformly spread over a $5.5-\mathrm{cm}^{2}$ irradiation area in a $500-\mathrm{ml}$ quartz vessel. Prior to the injection of $6 \mu \mathrm{mol}(\sim 300 \mathrm{ppm})$ gaseous 2-propanol, the organic pollutants (originating from the air) absorbed on the surface of the photocatalysts were first photo-oxidized into $\mathrm{CO}_{2}$ and the gas in the quartz vessel was then replaced with pure synthetic air (in the absence of $\mathrm{CO}_{2}$ and organic pollutants). Following the injection of 2-propanol, the reaction vessel was kept in the dark overnight and was then subjected to visible light irradiation to start the photocatalytic reactions. The concentrations of acetone and $\mathrm{CO}_{2}$ produced were monitored using a gas chromatograph (model GC-8A, Shimadzu Co., Ltd.).

\section{Results and Discussion}

\subsection{Characterization of the Prepared Electrodes and Powders}

Figure 1 shows XRD patterns of $\mathrm{n}-\mathrm{Si} / \mathrm{WO}_{3}$ and $\mathrm{p}-\mathrm{Si} / \mathrm{WO}_{3}$ electrodes. The faces of $\mathrm{n}-\mathrm{Si}(100)$ and $\mathrm{p}-\mathrm{Si}(100)$ were utilized to deposit $\mathrm{WO}_{3}$, so the peak at $\sim 69^{\circ}$ corresponding to (400) should be large, and in fact the extremely large (400) peak of n-Si was observed. However, that of p-Si was not so large, which would be attributable to the deviation from the right angle in setting $\mathrm{p}-\mathrm{Si} / \mathrm{WO}_{3}$ to the sample holder of the XRD apparatus. The peaks originated from $\mathrm{WO}_{3}$ on both $\mathrm{n}$-Si and $\mathrm{p}$-Si wafers were quite similar, and $\mathrm{WO}_{3}$ on both wafers was confirmed to have a single phase, probably the triclinic phase. $\mathrm{WO}_{3}$ in both $\mathrm{n}-\mathrm{Si} / \mathrm{WO}_{3}$ and $\mathrm{p}-\mathrm{Si} / \mathrm{WO}_{3}$ powders was confirmed to have a single phase of triclinic $\mathrm{WO}_{3}$ in the obtained XRD patterns (Figure 2). As for Si, being different from Figure 1, all the peaks originating from cubic $\mathrm{Si}$ were observed although some of the peaks overlapped with those from $\mathrm{WO}_{3}$. The peak intensity of $\mathrm{Si}$ was not as high as that 


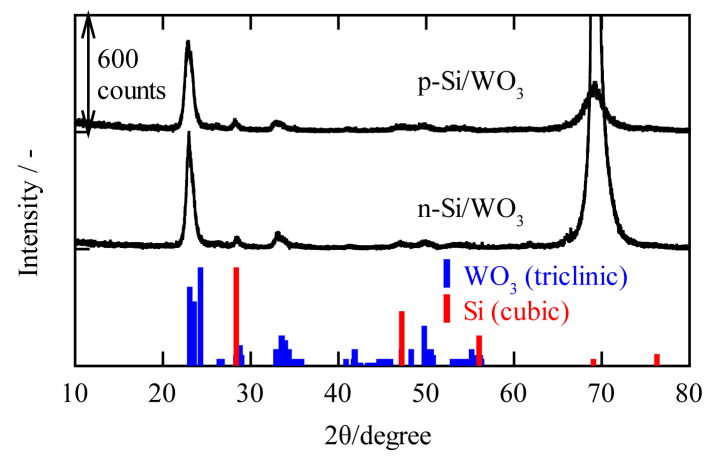

Figure 1. XRD patterns of the prepared $n-S i / \mathrm{WO}_{3}$ and $\mathrm{p}-\mathrm{Si} / \mathrm{WO}_{3}$ electrodes.

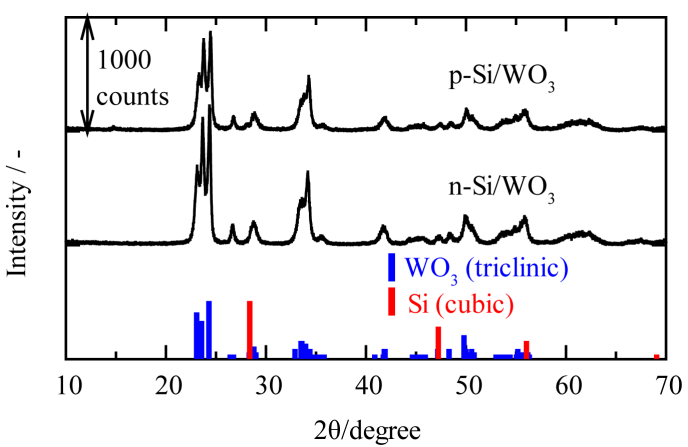

Figure 2. XRD patterns of the prepared $n-\mathrm{Si} / \mathrm{WO}_{3}$ and $\mathrm{p}-\mathrm{Si} / \mathrm{WO}_{3}$ powders.

of $\mathrm{WO}_{3}$ because $\mathrm{WO}_{3}$ powders completely covered the surface of $\mathrm{Si}$ as discussed below.

Figure 3 shows the cross sectional SEM image of the $\mathrm{n}-\mathrm{Si} / \mathrm{WO}_{3}$ electrode. The dense $\mathrm{WO}_{3}$ film with a thickness of $\sim 200 \mathrm{~nm}$ was observed, similar to $\mathrm{p}-\mathrm{Si} / \mathrm{WO}_{3}$ (not shown here). In Figure 4, the SEM image of the $\mathrm{n}-\mathrm{Si} / \mathrm{WO}_{3}$ powder is shown. The entire surface of each Si powder was covered (Figure 4(a)) by the needle-like $\mathrm{WO}_{3}$ powders (Figure 4(b)), which coincided well with the results of Deki et al. [27]. Figure 5 shows the UV-visible absorption spectra for commercially available $\mathrm{WO}_{3}$, prepared $\mathrm{n}-\mathrm{Si} / \mathrm{WO}_{3}$ and $\mathrm{p}-\mathrm{Si} / \mathrm{WO}_{3}$ powders. The absorption over a wider wavelength region $(>500 \mathrm{~nm})$ clearly increased for $\mathrm{n}-\mathrm{Si} / \mathrm{WO}_{3}$ and $\mathrm{p}-\mathrm{Si} / \mathrm{WO}_{3}$, indicating the successful connection of $\mathrm{WO}_{3}$ and $\mathrm{n}-$ or $\mathrm{p}-\mathrm{Si}$. In addition, the absorptions over $500 \mathrm{~nm}$ of $\mathrm{n}-\mathrm{Si} / \mathrm{WO}_{3}$ and $\mathrm{p}-\mathrm{Si} / \mathrm{WO}_{3}$ were similar within a several percent, so the amounts of $\mathrm{WO}_{3}$ connected to $\mathrm{n}-\mathrm{Si}$ and $\mathrm{p}-\mathrm{Si}$ were presumed to be similar.

\subsection{I-V Analysis}

We examined the I-V analysis in the dark and under light irradiation as shown in Figure 6. The typical rectifying I-V (typical p-n junction) behavior in $\mathrm{p}-\mathrm{Si}$ / $\mathrm{WO}_{3}$ was observed, particularly, under irradiation with light. It is plausible to consider the contact of $\mathrm{p}-\mathrm{Si}$ and $\mathrm{WO}_{3}$ (n-type semiconductor). That is, $\mathrm{p}-\mathrm{Si}$ has the more negative energy of Fermi level $\left(E_{f}\right)$ than that of $\mathrm{WO}_{3}$ when we consider 


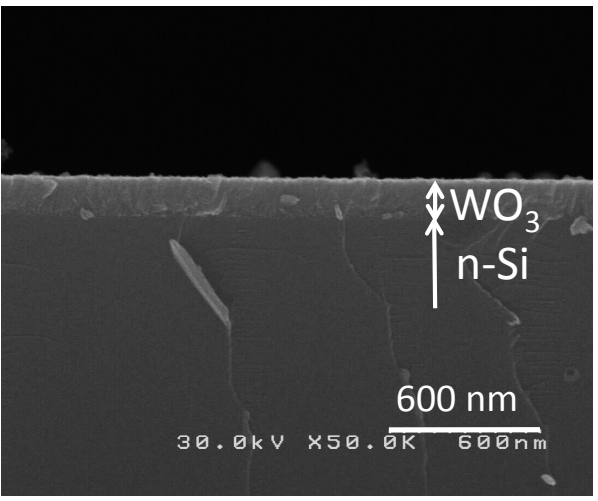

Figure 3. A cross sectional SEM image of the $\mathrm{n}-\mathrm{Si} / \mathrm{WO}_{3}$ electrode.
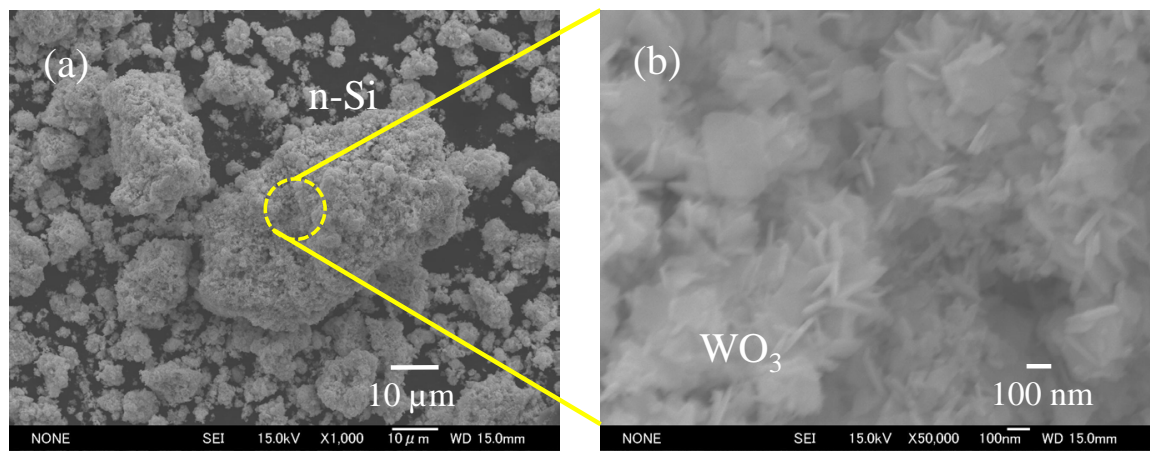

Figure 4. SEM images of the $\mathrm{n}-\mathrm{Si} / \mathrm{WO}_{3}$ powder. (b) is the enlargement of (a).

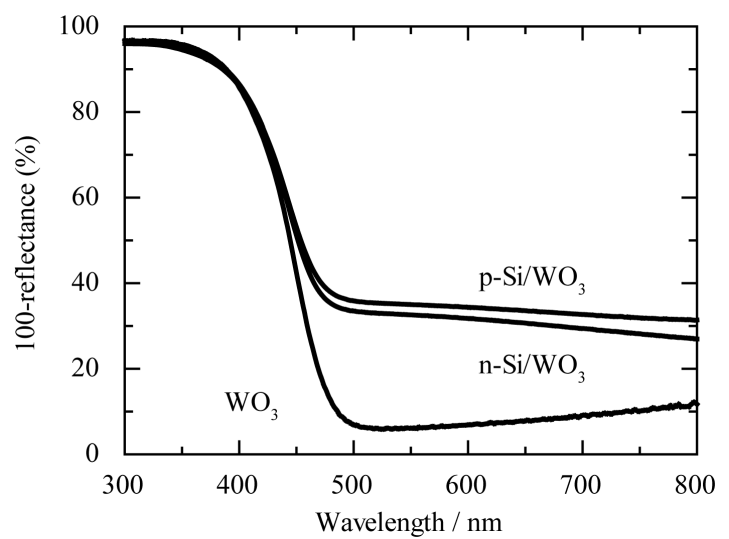

Figure 5. UV-visible absorption spectra of $\mathrm{WO}_{3}, \mathrm{n}-\mathrm{Si} / \mathrm{WO}_{3}$ and $\mathrm{p}-\mathrm{Si} / \mathrm{WO}_{3}$ powders.
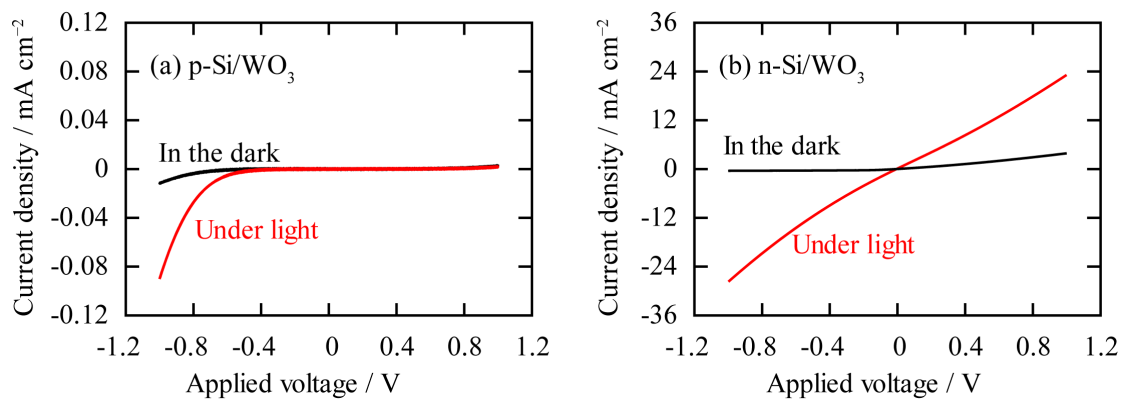

Figure 6. I-V characteristics of (a) p-Si/ $\mathrm{WO}_{3}$ and (b) n-Si/ $\mathrm{WO}_{3}$ heterojunctions. 
the vacuum level as zero energy (Scheme 2(a)). In contrast, the ohmic I-V characteristic in $\mathrm{n}-\mathrm{Si} / \mathrm{WO}_{3}$ was observed. As shown in Scheme $2(\mathrm{~b}), \mathrm{WO}_{3}$ has the more negative energy of $E_{f}$ than that of $\mathrm{n}-\mathrm{Si}$, so it is probable to form the ohmic contact between $\mathrm{n}-\mathrm{Si}$ and $\mathrm{WO}_{3}$. In addition, irradiated with light, the current density of $\mathrm{n}-\mathrm{Si} / \mathrm{WO}_{3}$ was demonstrated to be much larger than that of $\mathrm{p}-\mathrm{Si} / \mathrm{WO}_{3}$. This means that the interparticle charge transfer, that is, charge transfer between photo generated holes in the valence band (VB) of $\mathrm{n}$-Si and photoexcited electrons in the conduction band (CB) of $\mathrm{WO}_{3}$ proceeded (Scheme 2(b)). Such an ohmic I-V characteristic was also observed in $\mathrm{In}_{2} \mathrm{O}_{3}-\mathrm{Cu}_{2} \mathrm{O}$ system with poorphotovoltaic properties [28]. However, we can anticipate that the ohmic contact will function positively in terms of photocatalytic activity as discussed below.

\subsection{Decomposition of Gaseous 2-Propanol}

We next examined the 2-propanol decomposition in the presence of the $\mathrm{p}$-Si/ $\mathrm{WO}_{3}$ and $\mathrm{n}-\mathrm{Si} / \mathrm{WO}_{3}$ photocatalysts under visible-light irradiation (Figure 7). In the presence of $\mathrm{n}-\mathrm{Si} / \mathrm{WO}_{3}$, the evolved acetone initially increased and then decreased. This decrease was accompanied by the increase in the $\mathrm{CO}_{2}$ production. This behavior is plausible as it is known that 2-propanol decomposes into $\mathrm{CO}_{2}$, which is the final product, via acetone, the intermediate product [29]. In contrast, in the presence of $\mathrm{p}-\mathrm{Si} / \mathrm{WO}_{3}$, both acetone and $\mathrm{CO}_{2}$ increased monotonically up to irradiation time of $\sim 330 \mathrm{~h}$. We cannot exclude the possibility that the acetone concentration would decrease after further irradiation of visible light, accompanied by the increase in the $\mathrm{CO}_{2}$ evolution in the presence of $\mathrm{p}-\mathrm{Si} / \mathrm{WO}_{3}$. Even in such a case, it is readily apparent that the $\mathrm{CO}_{2}$ generation rate was smaller compared to that of $\mathrm{n}-\mathrm{Si} / \mathrm{WO}_{3}$ during the acetone-increasing period. In addition, the longer acetone-increasing period indicates that acetone is reluctantly decomposed to $\mathrm{CO}_{2}$ in the presence of $\mathrm{p}-\mathrm{Si} / \mathrm{WO}_{3}$. It is generally accepted that 2-propanol is easily decomposed to acetone; however acetone is hardly decom

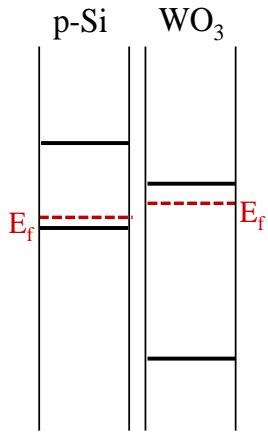

Before connection

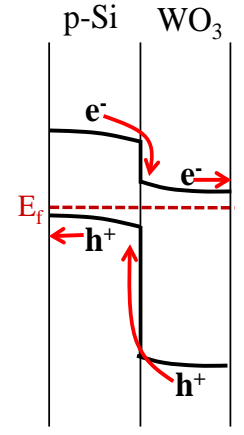

After connection

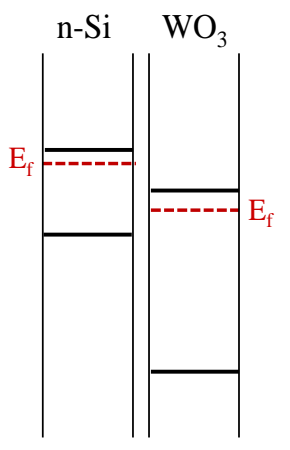

Before connection

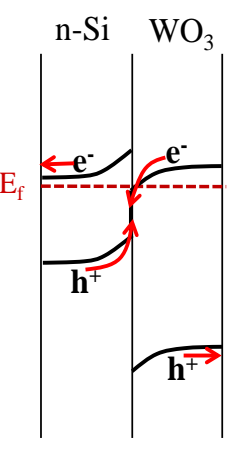

After connection

(a)

(b)

Scheme 2. Band alignments of (a) before and after connection of $\mathrm{p}-\mathrm{Si}$ and $\mathrm{WO}_{3}$, and (b) that of $\mathrm{n}-\mathrm{Si}$ and $\mathrm{WO}_{3}$. The charge transfer processes are also shown in the alignments after connection. 


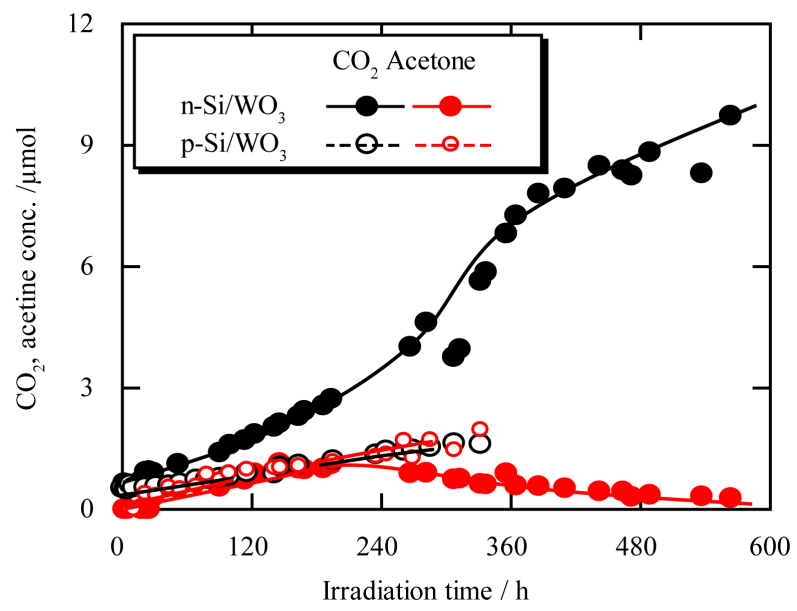

Figure 7. Changes in acetone and $\mathrm{CO}_{2}$ concentrations as functions of time in the presence of $\mathrm{n}-\mathrm{Si} / \mathrm{WO}_{3}$ and $\mathrm{p}-\mathrm{Si} / \mathrm{WO}_{3}$ under visible light irradiation.

posed to $\mathrm{CO}_{2}$. Thus, in any case, we can confidently conclude that the photocatalyticoxidative activity of $\mathrm{n}-\mathrm{Si} / \mathrm{WO}_{3}$ is much higher than that of $\mathrm{p}-\mathrm{Si} / \mathrm{WO}_{3}$.

It is well-known that the photo-produced holes play an important role in the generation of photocatalytic oxidative activity. In this sense, $\mathrm{WO}_{3}$ is a candidate for having holes with strong oxidative power because the VB top potential of $\mathrm{WO}_{3}$ is $3.1-3.2 \mathrm{~V}$ (vs. SHE, $\mathrm{pH}=0$ [30]). The potential is even more positive than that of anatase $\mathrm{TiO}_{2}(3.04 \mathrm{~V}$ vs. SHE, $\mathrm{pH}=0$ [31]), which has already been widely utilized as practical applications. The photo-generated electrons also play a crucial role in the generation of the photocatalytic oxidative activity. That is, to generate the photocatalytic oxidative activity, the photo-generated electrons need to be consumed in the $\mathrm{O}_{2}$ reduction because photocatalysts are usually utilized in air. If the photo-generated electrons are not consumed, the photo-produced holes will be recombined with them and eliminated. The CB bottom of $\mathrm{TiO}_{2}$ lies at $-0.16 \mathrm{~V}$ (vs. SHE, $\mathrm{pH}=0$ [31]), which is slightly more negative than that of one-electron $\mathrm{O}_{2}$ reduction $\left(\mathrm{O}_{2}+\mathrm{H}^{+}+\mathrm{e}^{-} \rightarrow \mathrm{HO}_{2},-0.046 \mathrm{~V}\right.$ vs. SHE, $\mathrm{pH}=0$ [31]). Thus, $\mathrm{O}_{2}$ reduction is expected to proceed in the $\mathrm{TiO}_{2}$ photocatalyst. In contrast, the $\mathrm{CB}$ bottom of $\mathrm{WO}_{3}$ lies at $0.3-0.5 \mathrm{~V}$ vs. SHE [30], so the photo-generated electrons cannot react with $\mathrm{O}_{2}$ through one-electron reaction. This is the reason why $\mathrm{WO}_{3}$ exhibits very low photocatalytic oxidative activity although the photo-produced holes in its VB have the strong oxidative power. To realize $\mathrm{WO}_{3}$ for the highly active photocatalyst, either Pt or $\mathrm{Cu}(\mathrm{II})$ is loaded on $\mathrm{WO}_{3}\left(\mathrm{Pt} / \mathrm{WO}_{3}, \mathrm{Cu}(\mathrm{II}) / \mathrm{WO}_{3}\right)$ [32] [33]. Again, $\mathrm{WO}_{3}$ exhibits very low photocatalytic oxidative activity because the photogenerated electrons cannot reduce $\mathrm{O}_{2}$ through the one-electron reaction reduction. Pt or electron injected $\mathrm{Cu}(\mathrm{II})$ (i.e., $\mathrm{Cu}(\mathrm{I})$ ) acts as a catalyst for multi-electron oxygen reduction (two electron reduction: $\mathrm{O}_{2}+2 \mathrm{H}^{+}+2 \mathrm{e}^{-} \rightarrow \mathrm{H}_{2} \mathrm{O}_{2}, 0.68 \mathrm{~V}$; or four-electron reduction: $\mathrm{O}_{2}+2 \mathrm{H}_{2} \mathrm{O}+4 \mathrm{H}^{+}+4 \mathrm{e}^{-} \rightarrow 4 \mathrm{H}_{2} \mathrm{O}, 1.23 \mathrm{~V}$ [32]).Thus the photogenerated electrons in either $\mathrm{Pt} / \mathrm{WO}_{3}$ or $\mathrm{Cu}(\mathrm{II}) / \mathrm{WO}_{3}$ are consumed in the multi-electron reduction 
of $\mathrm{O}_{2}$.

In the $\mathrm{n}-\mathrm{Si} / \mathrm{WO}_{3}$ system (Scheme $2(\mathrm{~b})$ ), we consider that the 2-propanol decomposition performance was derived from the photo-produced holes with the strong oxidative power that were generated in the $\mathrm{VB}$ of $\mathrm{WO}_{3}$ contributing to 2-propanol oxidation, and the photo-excited electrons that were generated in the $\mathrm{CB}$ of $\mathrm{n}$-Si contributing to $\mathrm{O}_{2}$ reduction through one-electron reaction. Importantly, the ohmic contact between $\mathrm{n}-\mathrm{Si}$ and $\mathrm{WO}_{3}$ acts as electron-and-hole mediator for the transfer of electrons and holes in the $\mathrm{CB}$ of $\mathrm{WO}_{3}$ and in the $\mathrm{VB}$ of $\mathrm{n}$-Si, respectively. Note that, to the best of our knowledge, $\mathrm{Si}$ (both n-Si and p-Si) does not function as the multi-electron $\mathrm{O}_{2}$ reduction catalyst. In the $\mathrm{p}-\mathrm{Si} / \mathrm{WO}_{3}$ system (Scheme 2(a)), the photo-produced holes in p-Si do not have the potential to oxidize 2-propanol, considering its VB top potential. Contrastly, a portion of the photo-produced holes in $\mathrm{WO}_{3}$ that exist on its surface across the Si particle can react with 2-propanol, and the photo-excited electrons reduce $\mathrm{WO}_{3}$ itself to produce protonated $\mathrm{WO}_{3}\left(\mathrm{H}_{x} \mathrm{WO}_{3-y}\right)$ and are eliminated. Thus, $\mathrm{p}-\mathrm{Si} / \mathrm{WO}_{3}$ exhibited the activity for the 2-propanol decomposition, however the activity was low.

\section{Conclusion}

We demonstrated the ohmic-contact $\mathrm{n}-\mathrm{Si} / \mathrm{WO}_{3}$ system that could decompose 2-propanolinto $\mathrm{CO}_{2}$ via acetone under irradiation with visible light in comparison with the rectifying-contact $\mathrm{p}-\mathrm{Si} / \mathrm{WO}_{3}$ system. These results point out a promising direction for producing an efficient photocatalyst by using the ohmic direct-connection with small band-gap materials to utilize the solar spectrum more efficiently.

\section{References}

[1] Fujishima, A. and Honda, K. (1972) Electrochemical Photolysis of Water at a Semiconductor Electrode. Nature, 238, 37-38. https://doi.org/10.1038/238037a0

[2] Hoffmann, M.R., Martin, S.T., Choi, W. and Bahnemann, D.W. (1995) Environmental Applicdations of Semiconductor Photocatalysis. Chemical Reviews, 95, 6996. https://doi.org/10.1021/cr00033a004

[3] Linsebigler, A.L., Lu, G. and Yates. Jr., T. (1995) Photocatalysis on $\mathrm{TiO}_{2}$ Surfaces: Principles, Mechanisms, and Selected Results. Chemical Reviews, 95, 735-758. https://doi.org/10.1021/cr00035a013

[4] Asahi, R., Morikawa, T., Ohwaki, T., Aoki, K. and Taga, Y. (2001) Visible-Light Photocatalysis in Nitrogen-Doped Titanium Oxides. Science, 293, 269-271. https://doi.org/10.1126/science.1061051

[5] Yoneyama, H., Koizumi, M. and Tamura, H. (1979) Photolysis of Water on Illuminated Strontium Titanium Trioxide. Bulletin of the Chemical Society of Japan, 52, 3449-3450. https://doi.org/10.1246/bcsj.52.3449

[6] Maeda, K., Teramura, K., Lu, D., Takata, T., Saito, N., Inoue, Y. and Domen, K. (2006) Photocatalyst Releasing Hydrogen from Water. Nature, 440, 295. https://doi.org/10.1038/440295a 
[7] Zou, Z., Ye, J., Sayama, K. and Arakawa, H. (2001) Direct Splitting of Water under Visible Light Irradiation with an Oxide Semiconductor Photocatalyst. Nature, 414, 625-627. https://doi.org/10.1038/414625a

[8] Maruyama, Y., Irie, H. and Hashimoto, H. (2006) Visible Light Sensitive Photocatalyst, Delafossite Structureda-AgGaO $\mathrm{A}_{2}$ The Journal of Physical Chemistry $B, 110$, 23274-23278. https://doi.org/10.1021/jp063406s

[9] Amao, F., Nogami, K., Abe, R. and Ohtani, B. (2008) Preparation and Characterization of Bismuth Tungstate Polycrystalline Flake-Ball Particlesfor Photocatalytic Reactions. The Journal of Physical Chemistry C, 112, 9320-9326. https://doi.org/10.1021/jp801861r

[10] Paola, A. D., Palmisano, L. and Augugliaro, V. (2000) Photocatalytic Behavior of Mixed $\mathrm{WO}_{3} / \mathrm{WS}_{2}$ Powders. Catalysis Today, 58, 141-149.

https://doi.org/10.1016/S0920-5861(00)00249-2

[11] Long, M., Cai, W., Cai, J., Zhou, B., Chai, X. and Wu, Y. (2006) Efficient Photocatalytic Degradation of Phenol over $\mathrm{Co}_{3} \mathrm{O}_{4} / \mathrm{BiVO}_{4}$ Composite under Visible Light Irradiation. The Journal of Physical Chemistry B, 110, 20211-20216. https://doi.org/10.1021/jp063441z

[12] Bessekhouad, Y., Robert, D. and Weber, J.-V. (2005) Photocatalytic Activity of $\mathrm{Cu}_{2} \mathrm{O} / \mathrm{TiO}_{2}, \mathrm{Bi}_{2} \mathrm{O}_{3} / \mathrm{TiO}_{2}$ and $\mathrm{ZnMn}_{2} \mathrm{O}_{4} / \mathrm{TiO}_{2}$ Heterojunctions. Catalysis Today, 101, 315-321. https://doi.org/10.1016/j.cattod.2005.03.038

[13] Gao, B., Ma, Y., Cao, Y., Yang, W. and Yao, J. (2006) Great Enhancement of Photocatalytic Activity of Nitrogen-Doped Titania by Coupling with Tungsten Oxide. The Journal of Physical Chemistry B, 110, 14391-14397. https://doi.org/10.1021/jp0624606

[14] Kim, H.G. and Jeong, E.D. (2006) Photocatalytic Ohmic Layered Nanocomposite for Efficient Utilization of Visible Light Photons. Applied Physics Letters, 89, Article ID: 064103. https://doi.org/10.1063/1.2266237

[15] Tada, H., Mitsui, T., Kiyonaga, T., Akita, T. and Tanaka, K. (2006) All-Solid-State Z-Scheme in CdS-Au-TiO 2 Three-Component Nanojunction System. Nature Materials, 5, 782-786. https://doi.org/10.1038/nmat1734

[16] Iwase, A., Ng, Y.H., Ishiguro, Y., Kudo, A. and Amal, R. (2011) Reduced Graphene Oxide as a Solid-State Electron Mediator in Z-Scheme Photocatalytic Water Splitting under Visible Light. Journal of the American Chemical Society, 133, 1105411057. https://doi.org/10.1021/ja203296z

[17] Kobayashi, R., Tanigawa, S., Takashima, T., Ohtani, B. and Irie, H. (2014) Silver-Inserted Heterojunction Photocatalysts for Z-Scheme Overall Pure-Water Splitting under Visible-Light Irradiation. The Journal of Physical Chemistry C, 118, 22450-22456. https://doi.org/10.1021/jp5069973

[18] Kobayashi, R., Kurihara, K., Takashima, T., Ohtani, B. and Irie, H. (2016) A Silver-Inserted Zinc Rhodium Oxide and Bismuth Vanadium Oxide Heterojunction Photocatalyst for Overall Pure-Water Splitting under Red Light. Journal of Materials Chemistry $A, 4$, 3061-3067. https://doi.org/10.1039/C5TA08468G

[19] Kobayashi, R., Takashima, T., Tanigawa, S., Takeuchi, S., Ohtani, B. and Irie, H. (2016) A Heterojunction Photocatalyst Composed of Zinc Rhodium Oxide, Single Crystal-Derived Bismuth Vanadium Oxide, and Silver for Overall Pure-Water Splitting under Visible Light up to $740 \mathrm{~nm}$. Physical Chemistry Chemical Physics, 18, 27754-27760. https://doi.org/10.1039/C6CP02903E

[20] Hara, Y., Takashima, T., Kobayashi, R., Abeyrathna, S., Ohtani, B. and Irie, H. (2017) Silver-Inserted Heterojunction Photocatalyst Consisting of Zinc Rhodium Oxide and Silver Antimony Oxide for Overall Pure-Water Splitting under Visible 
Light. Applied Catalysis B: Environmental, 209, 663-668. https://doi.org/10.1016/j.apcatb.2017.03.040

[21] Mayer, M.T., Du, C. and Wang, D. (2012) Hematite/Si Nanowire Dual-Absorber System for Photoelectrochemical Water Splitting at Low Applied Potentials. Journal of the American Chemical Society, 134, 12406-12409. https://doi.org/10.1021/ja3051734

[22] Khaselev, O., Bansal, A. and Turner, J.A. (2001) High-Efficiency Integrated Multijunction Photovoltaic/Electrolysis Systems for Hydrogen Production. International Journal of Hydrogen Energy, 26, 127-132. https://doi.org/10.1016/S0360-3199(00)00039-2

[23] Reece, S.Y., Hamel, J.A., Sung, K., Jarvi, T.D., Esswein, A.J., Oijpers, J.J.H. and Nicera, D.G. (2011) Wireless Solar Water Splitting Using Silicon-Based Semiconductors and Earth-Abundant Catalysts. Science, 334, 645-648. https://doi.org/10.1126/science.1209816

[24] Arai, T., Yanagida, M., Konishi, Y., Iwasaki, Y., Sugihara, H. and Sayama, K. (2007) Efficient Complete Oxidation of Acetaldehyde into $\mathrm{CO}_{2}$ over $\mathrm{CuBi}_{2} \mathrm{O}_{4} / \mathrm{WO}_{3} \mathrm{Com}$ posite Photocatalyst under Visible and UV Light Irradiation. Journal of Physical Chemistry Letters, 111, 7574-7577. https://doi.org/10.1021/jp0725533

[25] Jia, Q., Iwase, A. and Kudo, A. (2014) $\mathrm{BiVO}_{4}-\mathrm{Ru} / \mathrm{SrTiO}_{3}$ : Rh Composite Z-Scheme Photocatalyst for Solar Water Splitting. Chemical Science, 5, 1513-1519. https://doi.org/10.1039/c3sc52810c

[26] Yamane, S., Kato, N., Kojima, S., Imanishi, A., Ogaea, S., Yoshida, N., Nonomura, S. and Nakato, Y. (2009) Efficient Solar Water Splitting with a Composite " $n$-Si/ $p$-CuI / $n-i-p$ a-Si/n- $p$ GaP/RuO ${ }_{2}$ " Semiconductor Electrode. The Journal of Physical Chemistry $C, 113,14575-14581$. https://doi.org/10.1021/jp904297v

[27] Deki, S., Beleke, A.B., Kotani, Y. and Mizuhata, M. (2010) Synthesis of Tungsten Oxide Thin Film by Liquid Phase Deposition. Materials Chemistry and Physics, 123, 614-619. https://doi.org/10.1016/j.matchemphys.2010.05.024

[28] Tanaka, H., Shimakawa, T., Miyata, T., Sato, H. and Minami, T. (2004) Electrical and Optical Properties of TCO- $\mathrm{Cu}_{2} \mathrm{O}$ Heterojunction Devices. Thin Solid Films, 469-470, 80-85. https://doi.org/10.1016/j.tsf.2004.06.180

[29] Irie, H., Watanabe, Y. and Hashimoto, K. (2003) Nitrogen-Concentration Dependence on Photocatalytic Activity of $\mathrm{TiO}_{2-x} \mathrm{~N}_{x}$ Powders. The Journal of Physical Chemistry B, 107, 5483-5486. https://doi.org/10.1021/jp030133h

[30] Bamwenda, G.R., Sayama, K. and Arakawa, H. (1999) The Effect of Selected Reaction Parameters on the Photoproduction of Oxygen and Hydrogen from a $\mathrm{WO}_{3}-\mathrm{Fe}^{2+}-\mathrm{Fe}^{3+}$ Aqueous Suspension. Journal of Photochemistry and Photobiology A: Chemistry, 122, 175-183. https://doi.org/10.1016/S1010-6030(99)00026-X

[31] Torimoto, T., Nakamura, N., Ikeda, S. and Ohtani, B. (2002) Discrimination of the Active Crystalline Phases in Anatase-Rutile Mixed Titanium(IV) Oxide Photocatalysts through Action Spectrum Analyses. Physical Chemistry Chemical Physics, 4, 5910-5914. https://doi.org/10.1039/B207448F

[32] Irie, H., Miura, S., Kamiya, K. and Hashimoto, K. (2008) Efficient Visible LightSensitive Photocatalysts: Grafting $\mathrm{Cu}(\mathrm{II})$ Ions onto $\mathrm{TiO}_{2}$ and $\mathrm{WO}_{3}$ Photocatalysts. Chemical Physics Letters, 457, 202-205. https://doi.org/10.1016/j.cplett.2008.04.006

[33] Abe, R., Takami, H., Murakami, N. and Ohtani, B. (2008) Pristine Simple Oxides as Visible Light Driven Photocatalysts: Highly Efficient Decomposition of Organic Compounds over Platinum-Loaded Tungsten Oxide. Journal of the American Chemical Society, 130, 7780-7781. https://doi.org/10.1021/ja800835q 
Submit or recommend next manuscript to SCIRP and we will provide best service for you:

Accepting pre-submission inquiries through Email, Facebook, LinkedIn, Twitter, etc. A wide selection of journals (inclusive of 9 subjects, more than 200 journals)

Providing 24-hour high-quality service

User-friendly online submission system

Fair and swift peer-review system

Efficient typesetting and proofreading procedure

Display of the result of downloads and visits, as well as the number of cited articles Maximum dissemination of your research work

Submit your manuscript at: http://papersubmission.scirp.org/

Or contact msce@scirp.org 